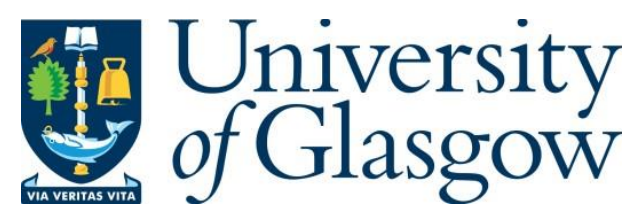

Walsh, D., McCartney, G. and O'Reilly, D. (2017) Potential influences on suicide prevalence in comparisons of UK post-industrial cities. Public Health, 143, pp. 94-96.

There may be differences between this version and the published version. You are advised to consult the publisher's version if you wish to cite from it.

http://eprints.gla.ac.uk/143786/

Deposited on: 28 July 2017

Enlighten - Research publications by members of the University of Glasgow http://eprints.gla.ac.uk 


\section{Potential influences on suicide prevalence in comparisons of UK post-industrial cities}

David Walsh' ${ }^{1}$, Gerry McCartney², Dermot O'Reilly ${ }^{3}$

1. Public Health Programme Manager, Glasgow Centre for Population Health, Olympia Building, 216 Orr Street, Bridgeton Cross, Glasgow G40 2QH, Scotland. Tel: 0141330 2793; Email: david.walsh.2@glasgow.ac.uk

2. Consultant in Public Health and Head of the Public Health Observatory team, NHS Health Scotland, Meridian Court, 5 Cadogan Street, Glasgow G2 6QE, Scotland; Email: gmccartney@nhs.net

3. Clinical Senior Lecturer, School of Medicine, Dentistry and Biomedical Sciences, Queen's University Belfast, University Road, Belfast BT7 1NN, Northern Ireland; d.oreilly@qub.ac.uk

Correspondence to: david.walsh.2@glasgow.ac.uk

Word count: 1,118 
Recent research has highlighted high levels of 'excess' mortality (defined as higher mortality after adjustment for differences in deprivation) in Glasgow compared to other UK post-industrial cities such as Liverpool and Manchester. The excess has been observed for many different causes of death, but is particularly high for suicide ${ }^{1}$. It has been suggested that a range of multiple, interlinked, factors are likely to be responsible for the overall excess: these include important, and damaging, historical processes and decisions impacting on the Scottish city - but that these have impacted alongside likely protective factors in operation in the English comparator cities which have placed Glasgow at a further relative disadvantage'. In Liverpool's case, and with particular reference to suicide, some authors have suggested that such protective factors (which would exacerbate Glasgow's relative disadvantage) might partly relate to differences in religion ${ }^{2}$ : we sought to explore this suggestion further through analysis of recently available data.

The important social and economic influences on suicide prevalence are well understood ${ }^{3}$. Rates of completed suicide are, for example, much higher among socio-economically deprived populations ${ }^{4}$. However, there are known protective factors, and alongside, for example, employment, social support and family connectedness, the role of religion has also been highlighted ${ }^{3}$. In part this relates to the benefits of religious participation for health outcomes generally ${ }^{5}$, but there is also international evidence of lower suicide rates among those of Roman Catholic faith compared to Protestants ${ }^{6}$ (something of course also shown historically by Durkheim ${ }^{7}$ ). One detailed study by Dorling and Gunnell ${ }^{2}$ modelled the impact of particular social and economic factors (described as indicators of 'social isolation') on suicide rates in Britain in the last two decades of the $20^{\text {th }}$ Century. The authors found that in the vast majority of places (British parliamentary constituencies) levels of suicide could be predicted by these ecological variables. However, there was a small number of areas which had significantly lower than expected rates, and areas which had higher than expected rates. The latter included deprived constituencies in Glasgow in Scotland, while the former included areas in and around Liverpool in North West England (both observations clearly reflecting the evidence of excess mortality in Glasgow compared to Liverpool ${ }^{1}$ ). Dorling and Gunnell speculated in reference to Durkheim's work - that the lower rates of suicide in Liverpool may be influenced by the high numbers of 'practising or believing' Catholics residents. However, this could not be verified: in the recent English censuses the question on religion does not distinguish between different Christian religions.

However, using data from a recent population survey of Glasgow, Liverpool and Manchester, we were able to further examine Dorling's and Gunnell's hypothesis (and thereby explore the potential relevance of this to the issue of excess mortality in Glasgow). The details of the survey have been published elsewhere ${ }^{8}$, and it has been shown to be broadly representative of the adult populations of the cities. It included the same religious affiliation question that was used in the 2011 Scottish census - which does distinguish between different Christian religions. Analyses of these data show that the percentage of the Liverpool sample describing themselves as Roman Catholic was indeed much higher than in Glasgow (and Manchester): 29\% compared to 18\% (and 12\%). This higher figure was seen in comparison of all adult age groups, and when stratified by gender ( $24 \%$ vs. $17 \%$ (and $12 \%$ ) of males, $34 \%$ vs. $18 \%$ (and $11 \%$ ) of females). This was also the case in analysis by

\footnotetext{
i See

http://www.gcph.co.uk/work themes/theme 1 understanding glasgows health/excess mortality comparin g glasgow
} 
neighbourhood deprivation level. Importantly, however, given the socio-economic influences on suicide highlighted above, the greatest differences were observed in comparison of the most deprived neighbourhoods of the two cities. This is shown in Figure 1.

[Figure 1 about here]

To a degree, therefore, these data would appear to support the suggestion that Liverpool's lower suicide rates compared to Glasgow's may be influenced by protective effects related to aspects of religious belief. Clearly, however, we must be very cautious in our interpretation of these analyses: a number of important limitations apply. First, the data are cross-sectional and are not linked to individual mortality records: there is therefore no evidence of causality. Second, the religion question employed in the survey asks about religious affiliation ('what religion, religious denomination or body do you belong to?'), rather than explicit religious belief, or participation in religion. This has been highlighted as problematic by a number of authors ${ }^{9}$. Indeed, analysis of a similar census question on religious affiliation included in the Northern Ireland census showed no significant association with mortality from suicide ${ }^{10}$. The survey also only provides data for three UK cities, and thus cannot be used to explore this issue in relation to comparisons of Liverpool with other UK areas which have higher suicide mortality rates (although it should be noted - in relation to these specific comparisons - that rates have been lower in Liverpool than in Manchester for many years ${ }^{11}$ ).All that said, however, the data included within this paper suggests that it is at least possible that aspects of religion may form part of a protective effect for Liverpool (alongside other, associated, characteristics of the population) which is relevant to achieving an understanding of the complex, multi-layered, reasons for excess levels of mortality in Glasgow relative to otherwise similar UK cities. As such, therefore, it warrants further research.

\section{DECLARATIONS}

Funding: The survey was jointly funded by NHS Health Scotland and the Glasgow Centre for Population Health

Competing interests: None declared

Ethical approval: The survey was approved by the University of Glasgow Medical Faculty Ethics Committee (project reference no. zFM06910). 


\section{References}

${ }^{1}$ Walsh D., Bendel N., Jones R., Hanlon P. It's not 'just deprivation': Why do equally deprived UK cities experience different health outcomes? Public Health 2010; 124: 487-495.

${ }^{2}$ Dorling D., Gunnell D. Suicide: the spatial and social components of despair in Britain 1980-2000. Transactions of the Institute of British Geographers 2003; 28(4): 442-460.

${ }^{3}$ McLean J., Maxwell M., Platt S., Harris F., Jepson R. Risk and protective factors for suicide and suicidal behaviour: a literature review. Edinburgh: Scottish Government Social Research; 2007

${ }^{4}$ Platt S., Boyle P., Crombie I., Feng Z., Exeter D. The epidemiology of suicide in Scotland 1989-2004: an examination of temporal trends and risk factors at national and local levels. Edinburgh: Scottish Executive Social Research; 2007.

${ }^{5}$ McCullough M.E., Hoyt W.T., Larson D.B., Koenig H.G., Thorensen C.E. Religious involvement and mortality: a meta-analytic review. Health Psychology 2000; 19(3): 211-222.

${ }^{6}$ Spoerri A., Zwahlen M., Bopp M. et al. Religion and assisted and non-assisted suicide in Switzerland: National Cohort Study. International Journal of Epidemiology 2010;39(6):1486-94.

${ }^{7}$ Durkheim E. Suicide. New York, NY, USA: The Free Press; 1951.

${ }^{8}$ Walsh D., McCartney G., McCullough S., van der Pol M., Buchanan D., Jones R. Exploring potential reasons for Glasgow's 'excess' mortality: results of a three-city survey of Glasgow, Liverpool and Manchester. Glasgow: Glasgow Centre for Population Health; 2013.

${ }^{9}$ Davie G. Religion in Britain since 1945: Believing without belonging. Oxford, UK: Blackwell; 1994.

${ }^{10}$ O'Reilly D., Rosato M. Religion and the risk of suicide: longitudinal study of over 1 million people. The British Journal of Psychiatry 2015; 206(6): 466-70.

${ }^{11}$ Office for National Statistics (ONS). Suicides in England and Wales by local authority, 2002-2014. Newport: ONS; 2016. Available from:

https://www.ons.gov.uk/peoplepopulationandcommunity/birthsdeathsandmarriages/deaths/datase ts/suicidesbylocalauthority (accessed October 2016) 